\title{
A Commitment to First Nations Data Governance: A Primer for Health Librarians
}

\author{
Kevin Read, Gail Mc Donald, Brad Mackay, and Eugene Barsky
}

Canada, along with the rest of the world, is currently in the throes of an information and communications revolution that is having a transformative effect on our society. Deep conceptual changes have been enabled, accelerated, and influenced by dynamic new technologies. This revolution reflects both the technologies themselves and the massive amounts of data that tools now capture and process, whether the data relates to consumer behaviour or health care. Data are rapidly becoming a torrent of new information flowing into every area of the global economy, society, and culture [1]. Data are becoming increasingly important in health research, and First Nations health research specifically [2], as the ease of data sharing provides an opportunity for new levels of respect, transparency, and accountability that are transforming how Canadian First Nations health research is governed. The widespread use of data also yields new opportunities for First Nations communities who are exercising ownership of, and support principled access to, the data collected from health research in which they participate.

Late in 2013, Canada's research funding agencies, the Social Sciences and Humanities Research Council, the Natural Sciences and Engineering Research Council, the Canadian Institutes of Health Research, and the Canada Foundation for Innovation - collectively the $\mathrm{TC} 3+$, in collaboration with Genome Canada-joined forces to address the challenges of data management and sharing.

In the consultation document Capitalizing on Big Data: Toward a Policy Framework for Advancing Digital Scholarship in Canada [3], these Canadian funders try to find workable solutions for the challenges that data present. $\mathrm{TC} 3+$ plans to work with other organizations and working groups to ensure ongoing consultation and coordination with all stakeholders, including the provinces, in the development of Canada's national digital infrastructure for research.

Early in 2012, two groups emerged out of stakeholder concerns regarding the sustainability and future develop- ment of Canada's advanced digital infrastructure ecosystem. The first was the Research Data Strategy Working Group, which morphed into Research Data Canada later that year [4]. It provides a forum for stakeholders to work together to enhance research data stewardship - the management, maintenance, and control of research data. The second was the Leadership Council for Digital Infrastructure [5], which focuses on the development of a national strategy to renew and strengthen Canada's advanced digital infrastructure ecosystem. Data management, sustainable funding, and integrated planning and sharing were identified as key issues to be addressed.

These developments are worth exploring in the context of Ownership, Control, Access, and Possession (OCAP), a set of principles that define how First Nations data can and should be used by researchers, governments, corporations, and other interested parties [6].

\section{OCAP principles and the First Nations Information Governance Centre}

The First Nations principles of OCAP originated in a 1998 brainstorming meeting of the National Steering Committee of the First Nations and Inuit Regional Longitudinal Health Survey. It was initially called "OCA"- for ownership, control and access - which served as an unintentional reminder of the Oka Crisis, a high-profile land dispute that took place in the summer of 1990 between Mohawk people and the town of Oka, Quebec. Not long after, when committee members recognized the importance of First Nations possessing their own data, the concept of data possession (and the subsequent letter " $p$ ") was added. OCAP as we know it was born.

OCAP was initially drafted to serve as a guide in the collection of data for the First Nations and Inuit Regional Longitudinal Health Survey and its eventual successor, the First Nations Regional Health Survey (FNRHS or RHS) [7], which collects information about health and wellness

Kevin Read, ${ }^{\mathbf{1}}$ New York University, 70 Washington Square S, New York, NY 10012, United States.

Gail Mc Donald and Brad Mackay. First Nations Information Governance Centre, 170 Laurier Avenue W, Suite 904Ottawa, ON K1P 5V5.

Eugene Barsky. University of British Columbia, Woodward Library, 2198 Health Sciences Mall, Vancouver, BCV6T 1 Z3.

${ }^{1}$ Corresponding author (e-mail: Kevin.read@nyumc.org). 
issues in 250 First Nations reserve and northern communities. In the 16 years since its inception the applications and scope of OCAP have grown significantly. From its successful application in First Nations communities across Canada to the trademarking of the "OCAP" name and the development of OCAP training workshops, OCAP reflects the commitment of First Nations people to the exercising of jurisdiction and governance over their own information.

The National Steering Committee eventually evolved into the First Nations Information Governance Committee, which operated at the Assembly of First Nations (AFN) and later received a mandate in 2009 from the AFN's Chiefs in Assembly to become the First Nations Information Governance Centre (FNIGC) - a federally incorporated, non-profit, First Nations entity founded in 2010 and based in Akwesasne, Ontario (with an office in Ottawa). In addition to serving as a home for OCAP, FNIGC administers two national surveys of First Nations communities: the RHS (which will enter its third cycle in 2014) and the First Nations Regional Early Childhood, Education and Employment Survey (FNREEES or REEES), which began initial deployment in the field in winter 2013 [7].

Though OCAP is relatively new, the ideas, themes, and values upon which it is built have existed among First Nations for generations. As such, it represents principles that are reflective of First Nations world views of jurisdiction, information governance, data protection, stewardship, and collective rights. OCAP has become synonymous with the best practices for how information about First Nations people should be gathered, stored, and accessed.

\section{Ownership}

The concept of data ownership is rooted in a First Nation community's relationship to its indigenous cultural knowledge. Much like how cultural knowledge is "owned" collectively, a community or group must own its information collectively - in the same way that individuals can expect to own their personal information.

\section{Control}

This principle asserts that First Nations people, their communities, and representative bodies must control how information about them is collected, used, and disclosed. The element of control extends to all aspects of information management, from collection of data to the use, disclosure, and protection of data.

\section{Access}

This principle refers to the concept that First Nations must have access to information and data about themselves and their communities, regardless of where it is held. This also refers to the right of First Nations communities and organizations to manage and make decisions regarding who can access their collective information.

\section{Possession}

This principle puts data within First Nation jurisdiction and therefore within First Nation control. Although ownership identifies the relationship between a people and their information in principle, possession (or stewardship) is more concrete. It refers to the physical control of data. First Nations generally have little or no control over data that are in the possession of others, which is why possession is a critical element of OCAP.

The need for a set of data governance principles and guidelines specific to First Nations is rooted in a decadeslong history of unethical and disrespectful information gathering in First Nations communities. The final report of the landmark Royal Commission on Aboriginal Peoples addressed this issue directly:

"In the past, Aboriginal people have not been consulted about what information should be collected, who should gather that information, who should maintain it, and who should have access to it. [...] Because data gathering has frequently been imposed by outside authorities, it has met with resistance in many quarters." [8]

Because the majority of researchers looking to collect data have traditionally been non-Aboriginal, a sense of distrust developed in First Nations communities. Examples of the misuse of First Nations information, particularly health information, are widespread. Misuse ranges from a researcher at the University of British Columbia who used unapproved blood samples from the Nuuchah-nulth First Nation under the auspices of a Health Canada study of rates of arthritis in the early 1980s [9] to Arizona State University researchers in the 1990s who gathered community health information taken from the Havasupai Tribe purportedly for a study of diabetes - only to use the information later to support published research on in-breeding, anthropological migration patterns, and schizophrenia [10].

An especially troubling example of poor information governance involves Health Canada's Non-insured Health Benefits Database (NIHB), which holds a significant amount of information about First Nations use of health services and goods such as prescription drugs, medical transportation, dental care, and medical devices. In 2001 Health Canada gave NIHB data about comprehensive pharmacy claims to Brogan Inc., a US-based health consulting and analysis firm, which in turn offered to sell the data to pharmaceutical companies for their own research. Health Canada removed personal identification information from the NIHB data but community identifiers remained. First Nations communities were not consulted or advised about the data transaction until 2007 when Health Canada advised the Assembly of First Nations about the extension of the Brogan contract [11]. Those involved in this disclosure were surprised that First Nations would be concerned about the release and eventual commercial use of their data.

Based on these and other precedents it became clear to many First Nations people and communities that government officials, researchers, academics, and corporations may not understand or support their interests. That is 
why OCAP was born and why it has flourished in the years since.

OCAP is currently housed and overseen by the FNIGC, which continues to apply the principles in the implementation of its two national survey initiatives, the RHS and REEES, which are carried out among 30,000 respondents in 10 regions across the country in collaboration with regional First Nations partners. The key to FNIGC's success is rooted in its adherence and respect of OCAP, which has come to represent the benchmark for ethical information collection and protection in First Nations communities.

In a response to increased interest in OCAP, FNIGC has also begun offering OCAP workshops (OCAMP) that give First Nations people the tools they need to implement OCAP in their communities and local governments. In 2014 it will also introduce a certification process where interested parties can apply for OCAP certification.

With OCAP, the FNIGC emphasizes the need to (i) develop clear research and data sharing agreements and set standards to ensure the protection and integrity of First Nations health data, (ii) organize data in a way that can be available and understood by others, and (iii) feel confident that this data will not be mismanaged so that their community can make decisions to inform future health research [6]. Other examples of developing data standards and policy for First Nation individuals are the British Columbia (BC) Tripartite Data Quality and Sharing Agreement (TDqSA) [12] and the Panorama Project [2]. The TDqSA promotes the sharing of First Nations health data among federal, provincial, and First Nations governments to improve the management of health data and enhance the delivery of health services, whereas the Panorama Project is a software system that promotes upto-date, high quality health data that are owned and operated by BC First Nations [13]. These efforts safeguard against any data being reported or analyzed without the consent of those in charge of First Nations data. The TDqSA promotes collaboration between First Nations and Canadian governing bodies to ensure that BC First Nations exercise ownership of their data and participate in the decision making process for the future use of the data. The OCAP principles are echoed by Joshua Tauberer, [14] who addresses 17 key principles to sharing open government data including timeliness, accessibility, provenance, and trust to promote the transparency, integrity, and rightful ownership of research data. These principles are essential for establishing an open model with respect to data creation and sharing in both government and health care settings.

Generally, for open data sharing to work effectively, data made publicly accessible must be comprehensible to anyone, whether experienced researcher or member of the public, so that it can be interpreted and evaluated. Sharing data is an important factor in the promotion of both data quality [15] and documentation of the provenance and integrity of the data over time [16-18]; if data are to be shared, it places the onus on those responsible for creating the data to be transparent and ensure that the data are collected ethically and according to their stated research methods. A key component of data sharing and the open data movement is to ensure that personally identifiable information is kept private by managing and documenting consent, safeguarding and controlling access to personal data, and ensuring the protection and accountability of personal health data [19]. These rules should be followed for all data that are collected from human subjects, so that incidents like those between First Nations communities and the NIHB can be avoided.

\section{Where do librarians fit in?}

Librarians have been long time advocates of the provision of access to timely, trusted, high quality information, and transitioning into the realm of research data represents the field's next logical step forward. To achieve the level of transparency, integrity, and quality that is compulsory for sharing data collected from health sciences research requires the expertise of information professionals who can support the collection, organization, management, and storage of these data. Librarians have been revamping [20, 21] their current services and knowledge bases to address the data management needs of their user groups to collect, organize, and preserve health research data [22]. The management and organization of research data are aligned with traditional library roles of collection development, providing reference services [23], and increasingly as embedded librarians [24-26] working alongside researchers to assist with information management. Librarians' expert knowledge of description, indexing, metadata, and digital library management further sets the stage for participation in data management and sharing efforts [20]. Assisting researchers to assign metadata descriptors to data, organize data produced from a research study, and catalogue data for discovery and interpretation in the future, are all examples of ways librarians can support data management. Finally, experiences with collection management and digital storage have afforded librarians with opportunities to expand their roles and turn into "data brokers," [27] where they appraise and store data within institutional repositories or data warehouses. This experience and expertise places librarians and libraries at the forefront for supporting health researchers in the open data initiative.

Canadian health sciences librarians are well positioned to support data storage and access of health research data through platforms such as the Canadian Virtual Health Library, which could expand its current list of health information resources to include research data repositories. Additionally, the Canadian Health Libraries Association and its provincial Chapters (e.g., Health Libraries Association of BC, Northern Alberta Health Libraries Association) can further their existing efforts to support health care research by advocating OCAP principles in the management and storage of health research data involving First Nations communities. Many libraries now provide instruction to researchers on the topics of data literacy, management, and preservation; these teaching models can be adjusted to recognize the unique needs of First Nations communities as owners and stewards of their own health data [28-31].

It is our role as information experts to step up and adapt to the new opportunities that data provide, and nowhere is this role more important than in the realm of health sciences research. In the health sciences, it is crucial that 
data be transparent, comprehensible, accessible, and protected so that First Nations communities, health researchers, and individuals participating in health research can prevent the misuse of data in the future.

\section{References}

1. Byers AH, Manyika J, Chui M, Brown B, Bughin J, Dobbs R, et al. Big data: The next frontier for innovation, competition, and productivity. McKinsey Global Institute; 2011. 156 p.

2. First Nations Health Council. 2013 Guidebook: Building Block for Transformation [Internet]. First Nations Health Authority. 2013. [cited 16 January 2014]. Available from: http://www.fnhc.ca/pdf/2013_Guidebook.pdf.

3. Capitalizing on Big Data: Towards a Policy Framework for Advancing Digital Scholarship in Canada [Internet]. Government of Canada. 2013 Oct 16 [cited 16 January 2014]. Available from: http://www.sshrc-crsh.gc.ca/about-au_sujet/ publications/digital_scholarship_consultation_e.pdf.

4. Research Data Canada [Internet]. Ottawa (ON): Government of Canada. 6 Dec 2012 [updated 14 Jan 2014; cited 16 Jan 2014]. Available from: http://rds-sdr.cisti-icist.nrc-cnrc.gc.ca/ eng/.

5. Leadership Council. Advancing Canada's Digital Infrastructure [Internet]. Ottawa $(\mathrm{ON})$ : Leadership Council for Digital Infrastructure. 2013 [cited 20 Jan 2014]. Available from: http://digitalleadership.ca/.

6. First Nations Centre. OCAP: Ownership, Control Access and Possession [Internet]. Ottawa (ON): National Aboriginal Health Organization; Sanctioned by First Nations Information Governance Committee, Assembly of First Nations. 2007 [cited 16 January 2014]. Available from: http://cahr.uvic. $\mathrm{ca} /$ nearbc/documents/2009/FNC-OCAP.pdf.

7. First Nations Regional Health Survey [Internet]. Ottawa (ON): First Nations Health Council. 2011 [cited 20 January 2014]. Available from: http://www.fnhc.ca/index.php/initiatives/ research_and_data/regional_health_survey.

8. Report of the Royal Commission on Aboriginal Peoples [Internet]. Ottawa (ON): Government of Canada. 2011 Nov 15 [cited 5 Jan 2014]. Available from: http://www.collectionsca nada.gc.ca/webarchives/20071115053257/http://www.ainc-inac. gc.ca/ch/rcap/sg/sgmm_e.html.

9. Dalton R. Tribe blasts 'exploitation' of blood samples. Nature. 2002;420(11). doi: 10.1038/420111a.

10. Drabiak-Syed K. Lessons from Havasupai Tribe v. Arizona State University Board of Regents: Recognizing Group, Cultural, and Dignitary Harms as Legitimate Risks Warranting Integration into Research Practice. $J$ Health Biomed Law. 2010;6(2):175-226.

11. Dumas A, Chapman M (Assembly of First Nations, Ottawa, ON). Data Sharing Agreement: First Nations Inuit Health Branch (FNIHB) and Brogan Consulting Inc. Winnipeg (MB): Annual General Assembly (CAN); 2010 Jul. 3 p. Resolution No.: 30/2010.

12. B.C. Tripartite Framework Agreement on First Nation Health Governance [Internet]. Tripartite Committee on First Nations Health Annual Report. Tripartite First Nations
Health Plan. 2012-2013 [cited 30 December 2013]. Available from: http://www.health.gov.bc.ca/library/publications/year/ 2013/Together-in-Wellness.pdf.

13. Mallory K. BC First Nations Panorama Implementation Project. Tripartite First Nations Health Plan. 2010.

14. Tauberer J. Open Government Data. Civic Impulse LLC; 2012.

15. Giarlo MJ. Academic Libraries as Data Quality Hubs [Internet]. State College, PA; 2012 [cited 2 January 2014]. p. 1-20. Available from: https://scholarsphere.psu.edu/files/ g732d898n.

16. Piwowar H, Vision TJ. Data reuse and the open data citation advantage. PeerJ [Internet]. 2013 [cited 25 January 2014]. 1(1). Available from: https://peerj.com/preprints/1.pdf.

17. Tenopir C, Allard S, Douglass K, Aydinoglu AU, Wu L, Read E, et al. Data sharing by scientists: practices and perceptions. PLoS One [Internet]. 2011 Jan [cited 27 Feb 2013]; 6(6):e21101. Available from: http://www.pubmed central.nih.gov/articlerender.fcgi?artid $=3126798 \&$ tool $=$ pmcen trez\&rendertype $=$ abstract.

18. Royal Society. Science as an open enterprise. London (UK): The Royal Society Policy Centre; 2012. 104 p.

19. Canadian Institutes of Health Research. CIHR Best Practices for Protecting Privacy in Health Research [Internet]. Government of Canada. Ottawa (ON); 2005 [cited 15 January 2014]. Available from: http://www.cihr-irsc.gc.ca/ e/29072.html.

20. Cox A, Verbaan E, Sen B. Upskilling Liaison Librarians for Research Data Management. Ariadne A Web Print Mag. Internet Issues Libr. Inf. Spec. 2012;(70).

21. Auckland M. Re-skilling for Research. Research Libraries UK [Internet]. 2012 [cited 14 Jan 2013]. Available from: http://www.rluk.ac.uk/wp-content/uploads/2014/02/RLUKRe-skilling.pdf.

22. Salo D. Retooling Libraries for the Data Challenge [Internet] Web Mag. Inf. Prof. 2010 [cited 9 Nov 2012]. Available from: http://www.ariadne.ac.uk/issue64/salo.

23. Carlson J. Demystifying the data interview: Developing a foundation for reference librarians to talk with researchers about their data. Ref. Serv. Rev. [Internet]. 2012 [cited 25 Apr 2013]; Available from: http://docs.lib.purdue.edu/cgi/viewcon tent .cgi? article $=1186 \&$ context $=$ lib_research .

24. Covert-Vail L, Collard S. New Roles for New Times: Research Library Services for Graduate Students [Internet]. Washington (D.C); 2012 [cited 9 January 2014]. Available from: http://www.arl.org/storage/documents/publications/nrntgrad-roles-20dec12.pdf.

25. Tan MC, Maggio LA. Expert searcher, teacher, content manager, and patient advocate: an exploratory study of clinical librarian roles. J. Med. Libr. Assoc. [Internet]. 2013 Jan [cited 27 Feb 2013];101(1):63-72. Available from: http:// www.pubmedcentral.nih.gov/articlerender.fcgi?artid $=35431$ 40\&tool $=$ pmcentrez\&rendertype $=$ abstract .

26. Borgman CL. Research Data: Who will share what, with whom, when, and why? China-North Am. Libr. Conf. [Internet]. Beijing; 2010 [cited 11 Jan 2013] 21. Available from: http://works.bepress.com/borgman/238/. 
27. Borchert M, Bradbury S, Broadley P. Collaborating to develop research data management services and collections [Internet]. 2013 [cited 23 Apr 2013]. Available from: http:// eprints.qut.edu.au/59211/2/PRES_IATUL_2013_Borchert_ Bradley_Broadley_DataMgt_FINAL.ppt.

28. Creamer A. Creating an Online Research Data Management Course: A Conversation with Data Librarians Robin Rice and Stuart Macdonald [Internet]. Worcester (MA); 2011 [cited $\mathrm{xxx}$ xxxx xxxx]. Available from: http://esciencelibrary. umassmed.edu/rice_macdonald_interview.pdf.

29. Piorun M, Kafel D, Leger-Hornby T, Najafi S, Martin E, Colombo P, et al. Teaching Research Data Management: An Undergraduate/Graduate Curriculum. J. eScience Lib.
[Internet]. 2012 [cited 14 January 2014]. 1(1):46-50. Available from: http://escholarship.umassmed.edu/jeslib/vol1/iss1/8/.

30. Johnston L, Lafferty M, Petsan B. Training Researchers on Data Management: A Scalable, Cross-Disciplinary Approach. J. eScience Lib. [Internet]. 2012 [cited 8 Nov 2012];1(2). Available from: http://escholarship.umassmed.edu/ jeslib/vol1/iss $2 / 2 /$.

31. Smylie J, Anderson M. Understanding the health of Indigenous peoples in Canada: key methodological and conceptual challenges. Can Med A.J. [Internet]. 2006 Sep 12 [cited 20 Jan 2014];175(6). Available from: doi: 10.1503/ cmaj.060940. 